\title{
Residual effect of nitrogen levels and weed control methods on growth, yield and economics of wheat grown after rice
}

\author{
Vipin Kumar Shukla \\ Department of Agronomy, M.G.C. Gramodaya Vishwavidyalaya Chitrakoot, \\ Satna- 485780 (M.P.), India \\ H. S. Kushwaha \\ Department of Agronomy, JNKVV College of Agriculture, Rewa- 486001 (M.P.), India \\ S. K. Singh* \\ Food Corporation of India, Mokama, Patna- 803302 (Bihar), India \\ D. K. Malviya \\ Department of Agronomy, JNKVV College of Agriculture, Rewa-486001 (M.P.), India \\ R. K. Tiwari \\ Department of Agronomy, JNKVV College of Agriculture, Rewa-486001 (M.P.), India \\ *Corresponding author. E-mail: rupanksha.231302@gmail.com

\begin{abstract}
A field experiment was laid out in split plot design on residual effect of treatments comprising three nitrogen levels viz. $\mathrm{N}_{75}\left(\mathrm{~N}_{1}\right), \mathrm{N}_{100}\left(\mathrm{~N}_{2}\right)$ and $\mathrm{N}_{125}\left(\mathrm{~N}_{3}\right)$ in main-plot treatments and seven weed control treatments viz. ( $\mathrm{W}_{1}$-butachlor +1 Hand Weeding, $\mathrm{W}_{2}$-butachlor + 2 Mechanical Weeding, $W_{3}$-butachlor $+2,4-D, W_{4}$-bispyribac sodium, $W_{5}$-butachlor + bispyribac sodium, $\mathrm{W}_{6}-\mathrm{HW}-2, \mathrm{~W}_{7}$ - control) as sub-plot treatments conducted during 201516 and 2016-17 at the Rajaula Agriculture Farm, MGCGVV, Satna (M.P.) to study the residual effect of $\mathrm{N}$-levels and weed control methods on growth, yield and economics of wheat grown after rice. In case of succeeding wheat, the residual $125 \mathrm{~kg} \mathrm{~N} / \mathrm{ha}$ performed the best with respect to growth, yield-attributes with the result $31.11 \mathrm{q} / \mathrm{ha}$ grain yield and Rs.33509/ha income. While, under sub plot treatments, Hand weedings two times were recorded significant grain yield $(28.66 \mathrm{~g} / \mathrm{ha})$ and straw yield $(38.17 \mathrm{q} / \mathrm{ha})$ at $(\mathrm{P}<0.05)$ over control. However it was found non-significant different and also noticed higher over rest treatments. In this succession, Butachlor +2 , 4-D $(0.80 \mathrm{~kg} / \mathrm{ha})$ was higher but in second position and similar trend was observed in successive way with rest of treatments.
\end{abstract} \\ Abstract
}

Keywords: Economics, Nitrogen levels, Residual effect, Weed Control Methods, Yield

\section{Article Info}

DOI:10.31018/jans.v11i2.2022

Received: February 17, 2019

Revised: April 30, 2019

Accepted: May 4, 2019

\section{How to Cite}

Shukla, V.P. et al. (2019). Residual effect of nitrogen levels and weed control methods on growth, yield and economics of wheat grown after rice. Journal of Applied and Natural Science, 11(2): 327- 332 https://doi.org/10.31018/ jans.v11i2.2022

\section{INTRODUCTION}

Wheat (Triticum aestivum L.) is the second major cereal crop of India next to rice. In Madhya Pradesh, with its large area, enjoys diverse climatic and soil conditions suitable for a broad range of agricultural products. Agriculture sector in Madhya Pradesh forms the backbone of its economy. It contributes almost one-fourth of the Gross State Domestic Product (GSDP) and is the main source of employment for over 65 percent of the population and constitutes about $60-75$ percent of the rural income.

Conventionally full tillage (3-4 passes) is done for sowing of wheat. The nutrients applied to rice crop are not fully utilized, which leads to their residual effect on the succeeding wheat crop. Nitrogen is a major nutrient required in the larger amount in cereal crop. Huge losses of nitrogen due to various ways including by weeds is very common. However, weed infestation is a major constraint to get optimum wheat yield under residual effect of nitrogen level. To resolve this problem, herbicide is a wise option to manage weeds (Gianessi, 2013) as it is a low cost, less labour and time demanding (Parvez, 2013); and target specific method of weed control (Simmons, 2006). Herbicides are typically used for controlling weeds by applying in soil or foliage. It is expected to control weeds by chemical within the season of application, while it is unpredicted the persistency of herbicides in soil and their residual effect on the various crop growth. Although the use of herbicides creates public concern and receives much criticisms from naturalists and environments, but still herbicides are widely used for weed control in developed countries as well as in many developing countries like India. The area under herbicidal weed control has unexpectedly increased in India within last few years and it is not only for the increasing labor crisis or not for the cheap price of 
herbicides. Herbicide offers effective control on strong competing weeds and ensures competition free environment for better crop establishment. Therefore, herbicides has a role to greatly improve crop yield especially in wheat through effectual weed control under residual effect (Zahan, 2016) and that's why, adaptation level of herbicidal weed control is high in wheat at farmers' field (Gianessi, 2014). In India where overall cropping intensity is 1.91 , there is a high risk of using herbicides in rotational crops having high persistency in soil and continuous application of same herbicide repeatedly in the same field year after year increases the possibility of herbicide persistency in soil. Preferably, herbicide should remain chemically active long enough to provide satisfactory weed control up to critical period of weed competition during crop growing season and then it should degrade into inoffensive products.

Several studies have shown herbicides are not generally susceptible to leaching when applied to the soil. Weeds can be controlled by herbicides, but it can be affect soil bio-chemical properties. Kiran et al. (2015) observed that root length, shoot length, seedling vigour and seed yield of succeeding mungbean were not affected when bispyribac was applied in the previous transplanted rice. Uncontrolled weeds are reported to cause upto $66 \%$ reduction in wheat grain yield (Kumar et al., 2011) or even more depending upon the weed density, type of weed flora and duration of infestation. It was important to investigate the changes in morphological and reproductive parameters under residual effect of different $\mathrm{N}$-levels and weed control treatments. This was required in relation to the productivity and net income from wheat after rice under the existing agro-climatic conditions. Therefore, the present research was taken up.

\section{MATERIALS AND METHODS}

The field experiment was carried out during rainy seasons of 2015 and 2016 at the Rajaula Agriculture Farm, MGCGVV, Satna (M.P.). The soil of the experimental site was sandy-loam in texture

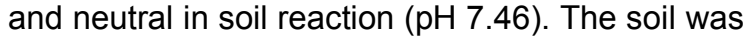
low in nitrogen, medium in phosphorus and high in potash. The total rainfall received during the crop season was $584.3 \mathrm{~mm}$ distributed in 31 rainy days. The experiment was laid out in split plot design on residual effect of treatments comprising three nitrogen levels viz. $\mathrm{N}_{75}\left(\mathrm{~N}_{1}\right), \mathrm{N}_{100}\left(\mathrm{~N}_{2}\right)$ and $N_{125}\left(N_{3}\right)$ in main-plot treatments and seven weed control treatments viz. ( $\mathrm{W}_{1}$-butachlor +1 Hand Weeding, $W_{2}$-butachlor +2 times Mechanical Weeding, $W_{3}$-butachlor $+2,4-D, W_{4}$-bispyribac sodium, $W_{5}$-butachlor + bispyribac sodium, $W_{6^{-}}$ Hand Weeding in 2 times, $W_{7-}$ control) as sub-plot treatments. Before transplanting rice crop, an uniform dose of $60 \mathrm{~kg} \mathrm{P} \mathrm{P}_{2}+40 \mathrm{~kg} \mathrm{~K} 2 \mathrm{O} /$ ha was applied in all the plots through SSP and MOP, re- spectively. Nitrogen was applied through urea in 3 split doses i.e. $50 \%$ at basal, $25 \%$ at tillering and $25 \%$ at panicle-initiation stages. The crop was harvested on 22 November 2015 and on 12 November 2016. The succeeding wheat crop (GW322) was sown @ 100 kg/ha on the same plots in which rice was harvested. It was shown on 20 November in 2015 and on 25 November in 2016 and harvested on 20 March in 2016 and on 27 March in 2017.

Statistical analysis : To test the significance, the experimental data collected on various aspects of the investigation on maize and soil were statistically analyzed with the procedure described by Cochran \& Cox (1967) and adopted by Cheema and Singh (1991) in statistical package CPCS-1. All the comparisons were made at $5 \%$ level of significance.

\section{Sampling techniques}

Plant population: The plant population per metre row length was recorded at 20 DAS from five row selected randomly and mean number of plants per metre row length was worked out and later converted into plants per square metre by multiplying with number of row in one metre area. For plant growth and yield attributes five randomly selected plants from each plot were tagged and their yield contributing characters were measured. Finally, mean was computed.

Seed yield: The seed yield per net plot was recorded after winnowing the produce. Finally, seed yield of each plot was converted into seed yield per hectare by multiplying with appropriate conversion factor.

Stover yield: The straw yield per plot was determined by subtracting seed yield (economical yield) of each plot from biological yield (bundle weight) of the same plot. This was later on converted in to straw yield per hectare by multiplying with the same conversion factor which was used in case of seed yield per hectare.

The observations on crop growth, yield attributes and yield were recorded in all the treatments at the time of harvest. Harvest index was calculated as the ratio of grain yield to the biological yield. It was calculated as per the formula proposed by Nichiporovich (1967).

$$
\text { Harvest Index }=\frac{\text { Economic yield }}{\text { Biological yield }} \times 100
$$$$
\text { Eq. } 1
$$

\section{RESULTS AND DISCUSSION}

Growth parameters: The data in Table 1 indicated that the highest level of residual nitrogen $\left(\mathrm{N}_{125}\right)$ resulted in significantly highest plant height, total and effective tillers/m length and dry weight/plant of wheat as compared to the lower levels of nitrogen. At the highest nitrogen level, the plant height 


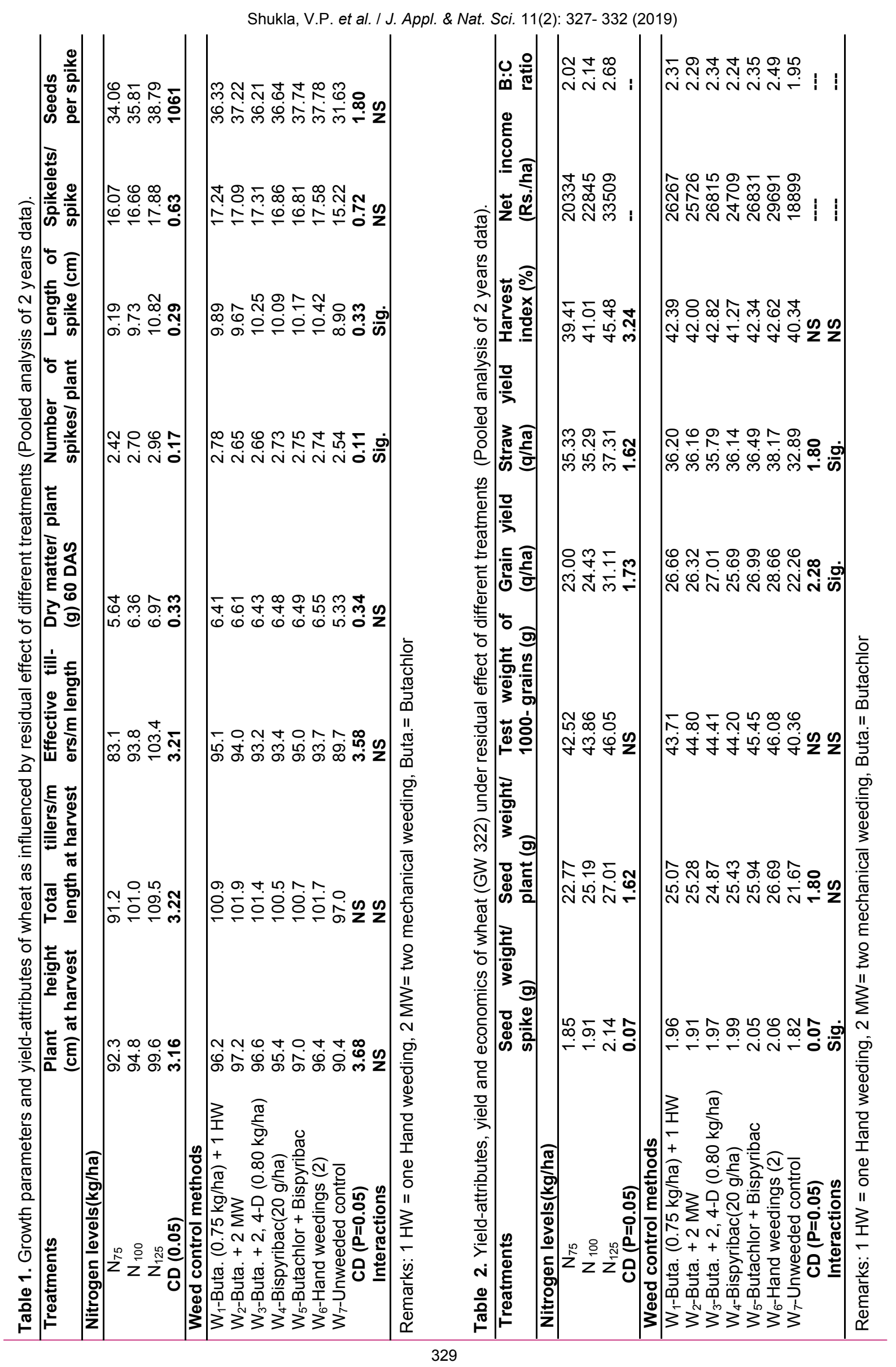


was significantly $(P<0.05)$, maximum $(99.6 \mathrm{~cm})$, total and effective tillers (109.5 and $109.4 / \mathrm{m}$ length, respectively) as well as dry weight $(6.97 \mathrm{~g} /$ plant) were noticed during experimentation. In fact, the trend and limit of vegetative growth before the start of reproductive phase is mainly governed by the genetically behaviour inherited in the high-yielding wheat plant type as well as by the crop management practices of the region.

The boosted vegetative growth (plant height and number of tillers/m length) due to increased nitrogen levels may be because of the fact that the applied nutrient promoted plant growth by ensuring higher number of greener leaves with increased photosynthesis. Profuse root development particularly due to increased availability of residual nitrogen insured more absorption of minerals, nutrients and soil moisture from the deeper soil layers. These favourable soil conditions brought about efficient utilization of plant nutrients accompanied by activating plant enzymes. The remarkable increase in plant height and formation of higher number of tillers $/ \mathrm{m}$ length due to higher doses of residual nitrogen associated activities may be as a result of acceleration of cell elongation and cell division. Moreover, these growth parameters were predominantly augmented by nitrogen levels which might be due to the fact that nitrogen being major nutrient is essential for building up of protoplasm and protein which induce cell division and enlargement with initial meristematic activity. Improvement in $\mathrm{P}$ uptake by wheat crop with $\mathrm{N}$ levels may be due to the increase in grain and straw yield and $\mathrm{P}$ content is corroborated by Jaga et al., (2017) and Grain and straw yields of wheat were 24.2 and $23.4 \%$ higher with $7.5 \mathrm{t}$ FYM/ha over control. The content and yield of protein increased significantly with the addition of $\mathrm{N}$ upto $120 \mathrm{~kg} \mathrm{~N} / \mathrm{ha}$ reported at Bichpuri, Agra, Uttar Pradesh by (Singh et al., 2017).

Amongst the residual effect of weed control treatments, $W_{1}$ to $W_{-6}$ resulted in almost equally significantly higher plant height, effective tillers and dry weight/plant in comparison to $\mathrm{W}_{7}$ (control). Among them, $\mathrm{W}_{2}$ - Buta. $+2 \mathrm{MW}$ was produced maximum plant height $(97.2 \mathrm{~cm})$, total tiller (101.9), dry weight $(6.61 \mathrm{~g})$ from series of treatments but noticed lower in effective tillers than $W_{1}$-Buta. $(0.75$ $\mathrm{kg} / \mathrm{ha})+1 \mathrm{HW}$ (95.1) during experimentation. This was due to equal effect of combined or separately applied herbicides as well as herbicides with mechanical/hand weeding. These treatments equally controlled existing weed-flora thereby avoided the wheat plants against weed competition for space, light soil-moisture and nutrients. Consequently, increased photosynthates in $W_{1}$ to $W_{6}$ treatments translocated from vegetative stage towards the reproductive organs of the plants. The beneficial influence of such treatments towards yieldattributes of wheat has also been reported by Ma- lik et al. (2004) reported that Clodinafop at $60 \mathrm{~g} / \mathrm{ha}$ applied after first irrigation yielded significantly higher grain yield over weedy check. Yadav et al. (2004),

Yield-attributes: The maximum $\mathrm{N}$-level up to $\mathrm{N}_{125}$ recorded significantly highest number of spikes (2.96/plant), spike length $10.82 \mathrm{~cm}$, spikelet $17.88 /$ spike, 38.79 seeds/spike, seed weight $2.14 \mathrm{~g} /$ spike, 1000 -seed weight $46.05 \mathrm{~g}$ and seed weight (27.01/plant) over the preceding $\mathrm{N}$-levels. The probable reason may be ascribed as it resulted in greater accumulation of carbohydrates, protein and their translocation to the reproductive organs which, in turn, increased the higher number of spikes and grain weight/plant as well as other yield-components. The increase in the yieldattributes due to nitrogen application to wheat has also been reported by many workers on wheat crops (Singh et al., 2013; Chauhan et al., 2014; Jat et al., 2014; Kumar et al., 2015 and Vinod kumar et al., 2017).

The yield-attributes of wheat (spikes/plant, length of spike, spikelets/spike, seeds/spike, seed weight/plant and 1000-seed weight were found equally significantly $(P<0.05)$ higher in case of $W_{1}$ to $W_{6}$ weed control methods over control $\left(W_{7}\right)$. This was due to the fact that each of the applied residual weed control treatments controlled the weeds upto equally maximum extent, thereby reducing the crop-weed competition for space, light, soil-moisture and nutrients. Consequently the increased photosynthates in $W_{1}$ to $W_{6}$ treatments translocated towards the reproductive organs of the wheat plants. The present findings have been supported by several researchers on the same crops (Yadav et al., 2004; Bhardwaj et al., 2004; and Jain, 2005).

Productivity of wheat: The application of highest $\mathrm{N}$-level $\left(\mathrm{N}_{125}\right)$ to rice (PS-5) significantly higher grain and straw yield of succeeding wheat as compared preceding $\mathrm{N}$-level. The overall grain and straw yield of wheat cV. GW 322 was found higher by 8.11 and $2.00 \mathrm{q} /$ ha due to $\mathrm{N}_{125}$ over lowest $\mathrm{N}_{75}$ (Summary Table 6.4). The trend of increases in grain and like straw yield obtained due to these treatments was exactly in accordance with the similar increases recorded in the yieldattributing characters (spikes/plant, seeds/spike, spike length, spikelets/spike, seed weight/spike, test weight and grain yield/plant, and the increased vegetative growth. The present findings are in accordance with those of many researchers on same crops (Singh et al., 2013; Chauhan et al., 2014; Jat et al., 2014; Kumar et al., 2015; Jaga et al., 2017; Singh et al., 2017 and Vinod Kumar et al., 2017).

The residual effect of different weed control treatments on the productivity of succeeding wheat was found to be influenced up to significant extent. Hand weeding twice $\left(\mathrm{W}_{6}\right)$ resulted in signifi- 
cantly higher grain and straw yield (28.66 and $38.17 \mathrm{q} / \mathrm{ha}$, respectively). This was closely followed by $W_{5}$ and then $W_{3}$. The higher productivity in these treatments might be owing to increased yield-attributing parameters. The dual herbicides in these treatments (butachlor $+2,4-\mathrm{D}$ and butachlor + bispyribac sodium) played unique and combined role in the control of weed-flora, which ultimately reduced the crop-weed competition for space, light, soil moisture and nutrients and consequently higher production of photosynthates and their translocation towards the reproductive organs responsible for the enhanced productivity. The significant role of dual herbicides in what productivity has been reported on wheat crops by Yadav et al. (2004), Jain (2005) and Kumar et al. (2005).

Economical gain from wheat: The highest level of nitrogen $\left(\mathrm{N}_{125}\right)$ applied to rice brought about the highest net-return from succeeding wheat up to Rs.33509/ha as revealed from Table 2. It was higher by Rs.13175/ha over the lowest $\mathrm{N}$-level $\left(N_{75}\right)$. This was eventual as the higher net return is directly correlated with the higher grain and straw production per hectare. In case of weed control treatments, $W_{6}$ (HW twice) recorded maximum net income upto Rs. 29691/ha. It was higher by Rs.10792/ha over control $\left(W_{7}\right)$. All the weed control treatments $\left(W_{1}\right.$ to $\left.W_{6}\right)$ proved almost equally effective in giving the net income ranging from Rs. 24709 /ha in case of $W_{4}$ to Rs. $26831 /$ ha in case of $\mathrm{W}_{5}$. This is in accordance with the seed yield/ha from these treatments. Vinod Kumar et al. (2017) also found that increasing levels of nitrogen up to $90 \mathrm{~kg} / \mathrm{ha}$ increased the net income and $\mathrm{B}: \mathrm{C}$ ratio from wheat (PBW-502). The application of respective noted treatment which given higher yield has significant result at level of $(P<0.05)$ over control in wheat crops. The different workers were noted the same result at different level of nitrogen and suggested that hand weeding may be done on availability of laborers on easily otherwise integrated weed management is best and will maintain sustainability.

\section{Conclusion}

On the basis of the experimental findings, it was concluded that application of $125 \mathrm{~kg}$ of $\mathrm{N}$ and two hand weeding has obtained maximum value of grain, straw as well as $B$ : $C$ ratio on residual effect after rice crop. However, the application of combined herbicide i.e. Butachlor + Bispyribac can be used satisfactorily to some extent than manual weeding in the regions where there is scarcity of laborers.

\section{REFERENCES}

1. Bhardwaj, S.K., Singh, R.K., Singh, S.P., Singh, Y., Singh, Govindra, Misra, R.D., Singh, Mahendra and Kumar, Abnish (2004). Weed management in zero- till sown wheat. Indian J. Weed Sci., 36(3\&4): 175177.

2. Cheema, H.S. and Singh, B. (1991). Software Statistical Package CPCS-1. Department of Statistics, Punjab Agricultural University, Ludhiana, India.

3. Cochran, W.G. and Cox, G.M. (1967). Experimental Designs. Asia Publishing House New Delhi. DACNET

4. Chauhan, T.M., Javed Ali, Singh, S.P. and Singh, S.B. (2014). Effect of nitrogen and zinc nutrition on yield, quality and uptake of nutrients by wheat. $A n$ nals of Plant and Soil Research, 16(2): 98-101.

5. Gianessi, L.P., (2013). The increasing importance of herbicides in worldwide crop production, Pest Management Science 69 (10) 1099-1105.

6. Gianessi, L.P. (2014). Importance of Pesticides for Growing Wheat in South Asia.

7. Jaga, P.K., Sharma, Satish and Patel, Yogesh (2017). Response of what to Azotobacter inoculation and nitrogen in soils of Vidisha, Madhya Pradesh. Annals of Plant and Soil Research, 19(1): 42-45.

8. Jain Namrata (2005). Effect of tillage practices and herbicides on weed dynamics and productivity of wheat in succession to transplanted rice. Ph. D. Thesis (Agronomy), JNKVV, Jabalpur (M.P.).

9. Jat, M.L., Bijay Singh and Gerard, B. (2014). Nutrient management and use efficiency in wheat sustains. Advances in Agronomy, 125: 171-259.

10.Kumar, V., Kumar, T., Singh, R.V., Singh, G. and Singh, R.A. (2015). Performance of real-time nitrogen management strategy in lowland area. Annals of Plant and Soil Research, 17(3): 314-317.

11.Kiran D.Y., Subramanyam, D., Sumathi, V., Reddy, G.P. (2015). Effect of pre and post emergence herbicides in transplanted rice and their Cumulative effect on succeeding greengram. Extended Summery. 25Th AsianPacific Weed Science Society Conference on "Weed Science for Sustainable Agriculture, Environment and Biodiversity, Hydrabad India, 231.

12.Malik, R.S., Balyan, R.S., Malik, R.K. and Pahwa, S.K. (2004). Grass weed control in wheat by clodinafop applied with and without surfactant. Indian J. Weed Sci., 36(1\&2): 8-11.

13. Nichiporovich AA. Photosynthesis of productive system. Jerusalem: Israel Programme Science Tansi, 1967, 182.

14.Parvez, M.S., (2013). Effect of cultivar and weeding regime on the performance of transplant aman rice, Intl. J. Agric. Crop Sci. 6 (11) 654.

15.Simmons, B., (2006). Soil properties and herbicide behavior, Proceedings: Indiana CCA Conference, Indianapolis, IN.

16.Singh, Dinesh Pratap and Singh, Dashrath (2017). Effect of nitrogen and FYM on yield, quality and uptake of nutrients in wheat. Annals of Plant and Soil Research, 19(2): 232-236.

17.Singh, V., Singh, S.P.S. and Shivay, Y.S. (2013). Growth, yield and nutrient uptake by wheat as affected by biofertilizers, FYM and nitrogen. Indian Journal of Agricultural Sciences, 83(3): 331-334.

18.Vinod Kumar, Kumar, T., Singh, G. and Singh, R.A. (2017). Effect of need based nitrogen management in wheat. Annals of Plant and Soil Research, 19(3): 243-247.

19.Yadav, A.K., Chauhan, S.K. and Shroti, S.K. (2012). Effect of sowing dates and nitrogen levels on yield and economics of vegetable pea-wheat-maize cropping system in central part of Uttar Pradesh. Annals 
Shukla, V.P. et al. / J. Appl. \& Nat. Sci. 11(2): 327- 332 (2019)

of Plant and Soil Research, 14: 159-162.

20.Yadav, Ashok, Malik, R.K., Banga, R.S., Dharam Bir, Malik, R.S. and Kumar, V. (2004). Bioefficacy of clodinafop, fenoxaprop, sulfosulfuron, tralkoxydim, dithiopyr and chlorsulfuron alone and in combination against compexflora of weeds in wheat. Indian $\mathrm{J}$. Weed Sci., 36(1\&2): 21-24.

21.Zahan, T. (2016). Weed control efficacy of herbicides in wheat under strip tillage system, Fund. Appl. Agri., 1 (2) 92-96. 